\title{
MEDIA KARTU BERGAMBAR UNTUK MENINGKATKAN PENGETAHUAN PROFESI BAGI SISWA SD KELAS ATAS
}

\author{
Dendy Setyadi \\ e-mail: dendysetyadi01@gmail.com \\ SD Tzu Chi Cengkareng \\ Jalan Kamal Raya, Cengkareng Tim., Kecamatan Cengkareng, Jakarta Barat
}

\begin{abstract}
Abstrak: Tujuan penelitian ini adalah untuk mengembangkan satu set produk yang dapat digunakan khususnya oleh siswa sebagai pengenalan profesi di Indonesia. Penelitian ini menggunakan metode 'Research and Development' yang dikembangkan oleh Borg dan Gall. Penelitian ini masuk dalam kategori "R \& D" skala kecil karena hanya menggunakan beberapa tahap yaitu: penelitian dan pengumpulan informasi, perencanaan, pengembangan format awal produk, validasi format awal produk, dan revisi produk. Hasil penelitian menunjukkan dari masing-masing validator yaitu penilaian ahli media 90,28\% (sangat baik), penilaian ahli materi 78,09\% (baik), dan penilaian siswa sebagai pengguna 78,52\% (sangat baik). Berdasarkan hasil validasi tersebut dapat disimpulkan bahwa media kartu bergambar dapat dikategorikan sebagai layak dengan persentase rata-rata 78,52\%. Media kartu bergambar ini diharapkan dapat diuji lebih lanjut untuk digunakan secara efektif, lebih lanjut penelitian ini diharapkan dapat diimplementasikan di sekolah lain.
\end{abstract}

Kata-kata kunci: Jenis profesi, informasi karier, kartu bergambar, siswa SD kelas atas

\section{PICTURE CARDS MEDIA TO IMPROVE OCCUPATION KNOWLEDGE FOR UPPER LEVEL ELEMENTARY SCHOOL STUDENT}

\begin{abstract}
The purpose of this research is to develop a set of picture products that can be used for students in particular as the introduction of occupations in Indonesia. 'Research and Development' method by Borg and Gall was used in this study. This research is categorized into small scale "RED" since it only used multiple stages, which were: research and information collecting, planning, developing of initial product format, initial product validating, and product revising. The result shows from each validator that media experts assess $90,28 \%$ (very decent), material experts assess 78,09\% (decent), and students as users assess 78,52\% (very decent). From these validations, it can be concluded that picture cards media can be categorized as worthy with the average percentage of $78,52 \%$. These picture cards media are expected to be tested further to be used effectively, furthermore this research is expected to be implemented in other schools.
\end{abstract}

Keywords: Career information, picture cards, occupations, elementary school students

\section{PENDAHULUAN}

Perkembangan ilmu pengetahuan serta teknologi dan informasi saat ini begitu pesat yang berdampak pada kehidupan manusia. Saat ini, kita memasuki revolusi industri 4.0 yang membutuhkan sumber daya manusia yang mampu menghadapi tantangan hidup dengan kemampuan yang baik. Untuk menghadapi perubahan dan perkembangan tersebut diperlukan kontribusi dalam berbagai bidang, salah satunya pendidikan. Pendidikan bertugas 
mempersiapkan generasi penerus sejak anak-anak, karena mereka adalah generasi penerus eksistensi bangsa.

Siswa sekolah dalam upaya terlibat dalam proses pendidikan memerlukan bimbingan, dimana bidang bimbingan dan konseling bertugas memberi bantuan secara berkesinambungan kepada individu agar dapat memahami dirinya dan bertindak wajar sebagai cara untuk memenuhi tuntutan keluarga dan masyarakat (Winkel dan Hastuti, 2010). Egbo (2015) mengatakan, bahwa bimbingan dan konseling benarbenar penting untuk memenuhi keperluan akademik, kejuruan, pribadi dan sosial anak-anak. Bimbingan konseling membantu anak untuk memaksimalkan citra diri yang positif dan mengaktualisasikan kebutuhan penyesuaian mereka untuk dibawa ke masa depan. Kecakapan, keterampilan dan kepribadian diharapkan dapat dimanfaatkan melewati program Bimbingan dan Konseling yang tepat sasaran di tingkat sekolah dasar. Guru bimbingan konseling mempunyai tugas menjalankan fungsi pemahaman, penyesuaian, fasilitas, adaptasi, penyesuaian, penyaluran, pencegahan, pengembangan, serta pemeliharan. Peserta didik dapat berkembang dengan optimal secara utuh, sedangkan hal yang dapat dilakukan guru adalah memberikan bimbingan karier pada siswa.

Revolusi industri keempat mengubah kesadaran profesi bagi generasi muda. Pola berkarir juga mengalami perubahan. Era ini ditandai dengan kehidupan yang didasarkan pada ketersediaan data dan kecerdasan buatan. Dibutuhkan kesiapan karir sejak dini yang dapat diberikan melalui bimbingan karir. Pada jenjang pendidikan dasar, khususnya sekolah dasar, karir adalah pada tahapan career awareness (kelas 1 SD sampai 6), yaitu kesadaran anak tentang berbagai pekerjaan. Kesadaran ini meliputi memahami, menghargai dan terampil dalam mengenal dirinya dan berbagai dunia karir disekitar (Lidyasari, 2019). Bimbingan diberikan agar siswa mempunyai gambaran tentang kehidupan yang akan datang, yaitu kehidupan sebagai pribadi, anggota masyarakat, serta warga negara. Bimbingan karier secara formal belum dikenalkan di dunia pendidikan dasar Indonesia (Winkel dan Hastuti, 2010). Bimbingan karier berfungsi sebagai rangkaian perkembangan karier manusia, khusunya dalam perencanaan karier sejak anak-anak.

Bimbingan karier di sekolah dasar telah dipandang oleh banyak orang sebagai bahan penting dalam proses pendidikan semua siswa (Zunker, 2006). Oleh karena itu, dapat disimpulkan bahwa perkembangan karier adalah proses seumur hidup. Namun demikian, program karier harus diberikan sesuai dengan usia. NOSCA (National Office for School Counselor Advocacy) (2012) mengatakan, bahwa sekolah dasar dapat menciptakan kesadaran, pengetahuan dan keterampilan dasar yang lebih awal. Perkembangan kognitif anak-anak sekolah dasar berada pada tahap operasional konkret menuju operasional formal. Menurut Suherman (2013), hal tersebut karena anak memiliki konsep kognitif yang semakin jelas. Oleh karena itu, pemberian informasi karier untuk anak sekolah dasar harus disesuaikan dengan perkembangan kognitifnya. Pemberian informasi serta pengenalan karier pada anak SD juga harus konkret serta dapat diterima anak SD kelas atas (kelas 4, 5, dan 6). Anak SD kelas atas memiliki tugas perkembangan karier mengenai pengenalan macam profesi dan kegiatan orang dalam kehidupan, menghargai macam profesi dan kegiatan sebagai hal yang saling bergantung (SKKPD, 2008). Ali dan Graham (1996), mengatakan bahwa bimbingan karier yang efektif adalah proses yang ditujukan untuk individu agar memperoleh pembekalan tentang pemahaman yang jelas kepada diri sendiri serta memiliki kekuatan untuk perkembangan karier di masa depan.

Saputro (2017) mengatakan bahwa terdapat empat hal mengapa bimbingan karier belum bisa dilaksanakan dengan baik. Empat hal tersebut, yaitu (a) kesibukan guru pembimbing ataupun guru kelas tidak dapat menguasai kelas, (b) pilihan materi yang kurang bervariasi, (c) memberikan materi yang membosankan, dan (d) ditinjau dari peserta didik, yaitu lingkungan sosial budaya serta keadaan ekonomi sosial. Dapat kita simpulkan, bahwa kinerja serta materi menjadi salah satu faktor bimbingan belum maksimal. Selain itu, pelaksanaan layanan bimbingan karier ini dihadapkan pada kesusahan dan hambatan. Hambatan tersebut timbul dan muncul dari berbagai macam hal, seperti anggota pengajar sekolah yang kurang memahami konsep bimbingan konseling, fasilitas yang kurang memadai, serta kurangnya dana untuk aktivitas bimbingan konseling.

Seperti penelitian Pranoto (2015) yang menyebutkan bahwa proses layanan bimbingan dan konseling oleh guru kelas di Sekolah Dasar Kabupaten Batang secara umum tergolong dalam kategori sedang. Proses layanan bimbingan dan konseling oleh guru kelas telah dijalankan, tetapi masih terdapat beragam kekurangan dan kendala di dalamnya. Kekurangan tersebut seperti administrasi bimbingan yang masih belum dihasilkan oleh sebagian besar guru kelas kemudian sarana prasarana yang kurang menunjang, 
ataupun guru kelas yang bukan tamatan Pendidikan Bimbingan Konseling.

Studi pendahuluan yang dilakukan di di SD Maria Asumppta Kabupaten Klaten kepada 74 orang siswa dengan cara observasi dan pengisian angket, ditemukan bahwa siswa hanya mengenali beberapa pekerjaan saja, seperti guru, polisi, tentara, penambang pasir, pedagang, pilot, dan dokter. Sama halnya dengan observasi serta wawancara pada anak-anak SD Cinta Kasih Tzu Chi Cengkareng, anak-anak hanya mengenal profesi pekerjaan yang sama. Padahal data dari Badan Pusat Statistik dalam Klasifikasi Baku Jenis Pekerjaan Indonesia membuat golongan pokok pekerjaan ada 10 kategori, dengan 599 klasifikasi pekerjaan (Badan Pusat Statistik, 2002). Jadi belum banyak pengetahuan mengenai berbagai macam profesi telah diketahui oleh siswa SD.

Di sekolah, termasuk sekolah dasar, terdapat kegiatan bimbingan karir. Biasanya dengan menggunakan bimbingan klasikal. Waktu bimbingannya pun terbatas. Bimbingan klasikal pada jenjang sekolah dasar memerlukan media yang sesuai dengan perkembangan kognitifnya. Media dapat membuat siswa tidak cepat jenuh dan mampu menerima materi dengan baik. Media ini dibutuhkan agar tujuan dari bimbingan dapat kita capai, khususnya dalam bimbingan karier. Akan tetapi, media yang tersedia untuk digunakan dalam kegiatan bimbingan karir sangat terbatas. Oleh karena itu, dibutuhkan pengembangan media untuk membantu siswa meningkatkan wawasan berbagai profesi. Termasuk strategi pemanfaatannya dalam kegiatan bimbingan karier melalui permainan untuk tujuan pembelajaran dalam konteks karier sebagai metode bimbingan.

Penelitian pengembangan ini menghasilkan media kartu bergambar untuk mengenalkan berbagai macam profesi pada siswa SD. Geldrad dan Geldrad (2012) mengatakan bahwa pemilihan media kartu sebagai alat adalah sesuai dengan aktivitas anak serta kemampuan dan kebutuhan anak. Faktor memilih media ini disesuaikan dengan cakupan usia perkembangan anak dan tujuan dari bimbingan saat ini pada anak. Maksudnya adalah dengan melihat gambar, siswa akan terbantu dalam memahami informasi dengan lebih baik. Ada penelitian sejenis sebelumnya yang telah dilakukan, yaitu Purwanta (1993) yang telah menghasilkan produk berupa gambar berbagai macam profesi sebagai media bimbingan karier di sekolah dasar. Hanani (2016), dalam penelitiannya menghasilkan produk kartu karier yang layak digunakan sebagai media permainan dalam bimbingan karier bagi siswa kelas 1, 2, dan 3SD di kelas rendah. Kartu dibagi menjadi dua, yaitu kartu karir dan kartu pilihan karir. Proses pengembangan Hanani masih terbatas untuk siswa SD kelas rendah, sehingga Ia menyarankan adanya pengembangan kartu karir yang terutama menambah jumlah jenis pekerjaan, materi, dan gambar yang lebih beragam.

Berdasarkan kajian penelitian terdahulu, media kartu bergambar dapat digunakan sebagai media pembelajaran, khususnya bagi siswa SD. Penelitian ini bertujuan untuk mengembangkan media permainan berbasis kartu bergambar profesi yang bisa dimanfaatkan untuk membantu siswa SD kelas atas untuk meningkatkan informasi profesi. Siswa SD kelas atas, secara kognisi dapat memperoleh kekayaan informasi akan jenis-jenis profesi yang bermuara dengan memiliki kemampuan menentukan arah peminatan yang tepat sesuai dengan kemampuan diri. Kartu bergambar profesi ini akan disesuaikan dengan profesi yang ada di Indonesia sesuai Klasifikasi Baku Jabatan Indonesia (KBJI). Pengembangan media kartu bergambar juga memiliki kelebihan. Kelebihan media kartu menurut Dwyer (dalam Budiningsih, 2003) adalah mudah dalam mengomunikasikan pesan secara tepat dan terstandar. Media kartu juga dapat digunakan dalam situasi, peristiwa ataupun perubahan waktu yang tidak mungkin karena keterbatasan ruang. Media kartu bergambar dapat menggambarkan, memperjelas dan memperkuat komunikasi secara lisan maupun tertulis. Memberikan hal-hal yang konkret dalam kondisi belajar. Meningkatkan minat serta rasa ingin tahu murid. Media yang dibuat mengacu kelayakannya dengan melihat kesesuaian antara konten dalam media pembelajaran dengan standar kemandirian peserta didik (SKKPD), sehingga media dapat dipakai sebagai media pembelajaran.

\section{METODE PENELITIAN}

Borg, Gall and Gall (2003) mengatakan bahwa penelitian serta pengembangan adalah contoh pengembangan berbasis industri yang inovasi penelitiannya dipakai untuk mendesain produk serta prosedur baru. Penelitian ini adalah penelitian pengembangan dengan tujuan menghasilkan produk tertentu, menguji keefektifan produk, serta menemukan pengetahuan baru melalui "basic research" atau untuk menjawab pertanyaan-pertanyaan khusus yang bersifat praktis melalui "applied research". Siklus pengembangan Borg, Gall \& Gall (2003) terdiri atas 10 (sepuluh) langkah seperti gambar berikut ini: 


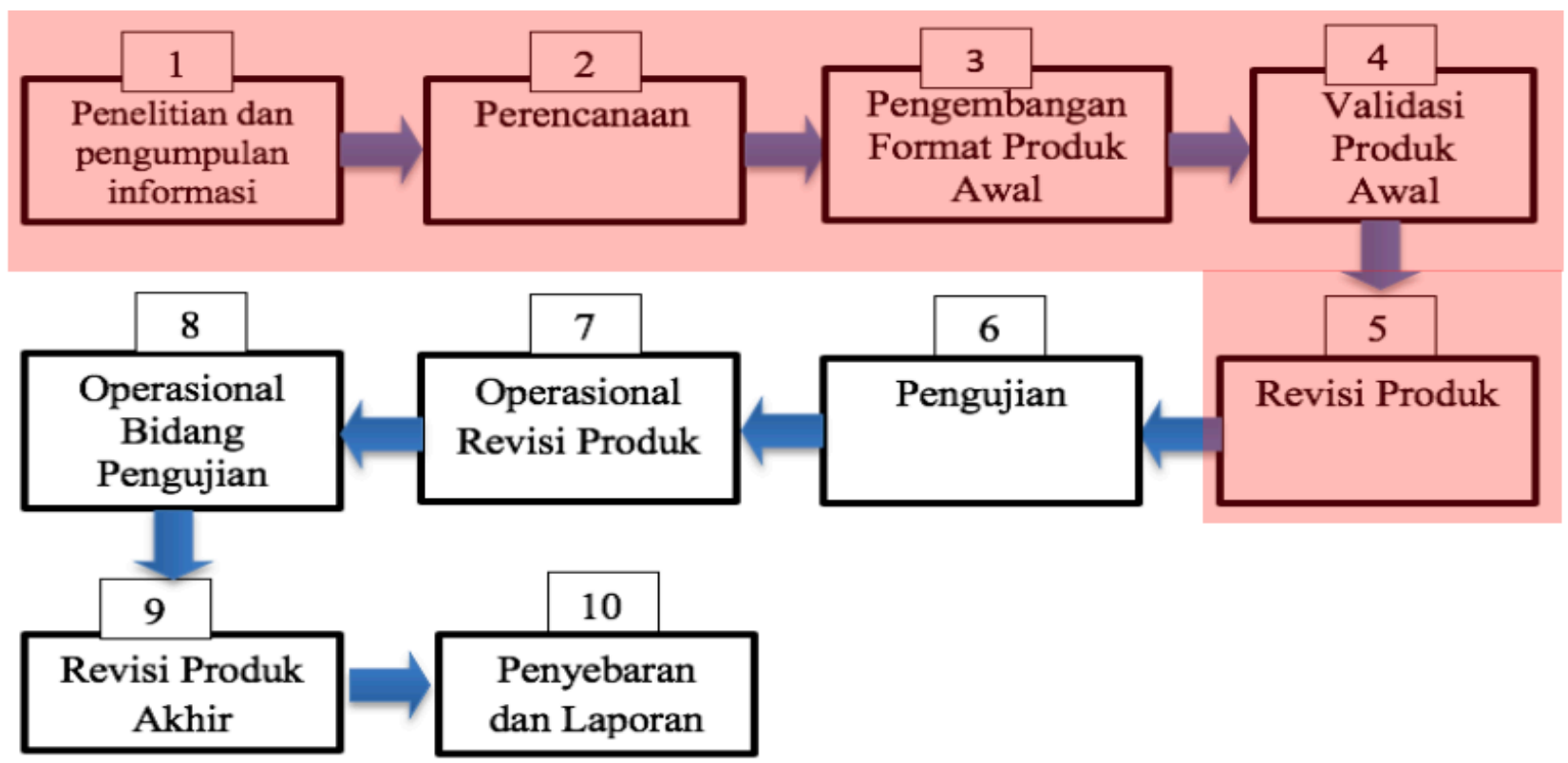

Gambar 1. Siklus dalam Penelitian Pengembangan (Borg, Gall, \& Gall, 2003)

Penelitian ini menghasilkan prototipe produk yang telah divalidasi dan diuji terbatas (skala kecil), sehingga bagian yang berwarna abu-abu adalah langkah yang diselesaikan dalam penelitian ini, yaitu langkah 1-5. Berikut ini siklus penelitian pengembangan Borg, Gall \& Gall yang digunakan dalam penelitian ini:

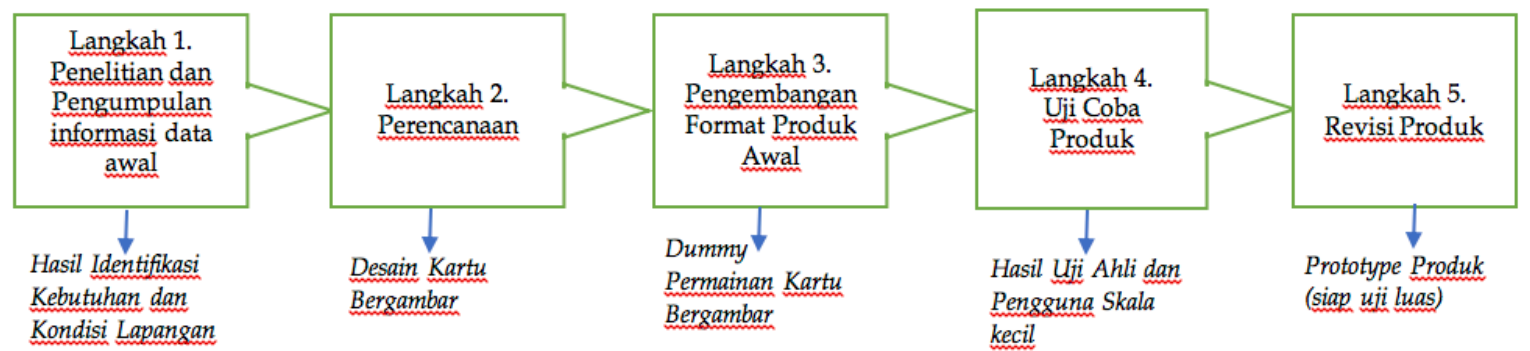

Gambar 2. Langkah penelitian yang dilakukan

Tabel 1.

Rencana Aktivitas Setiap Tahapan

\begin{tabular}{ll}
\hline Langkah 1 & Penelitian dan pengumpulan data atau \\
& informasi awal berupa identifikasi kebutuhan \\
& serta melakukan observasi awal yang terkait \\
& dengan sejauhmana pengenalan informasi \\
& profesi pada siswa sekolah dasar. Tahap awal \\
& ini bertujuan untuk memperoleh informasi \\
& awal untukmelakukan pengembangan produk. \\
& Pengumpulan data dengan menggunakan \\
& kuesioner \\
\hline Langkah 2 & Tahap Perencanaan adalah merencanakan \\
& pengembangan produk dengan menyusun \\
& rencana penelitian, merumuskan desain \\
& penelitian dalam lingkup terbatas. Sesuai \\
dengan hasil survei pada pengumpulan data & awal, dan melakukan studi dokumen melalui \\
& buku Klasifikasi Baku Jabatan Indonesia/KBJI \\
& tahun 2016 \\
\hline
\end{tabular}

Penelitian ini menggunakan siswa SD Asummpta Kabupaten Klaten sebagai partisipan

\begin{tabular}{ll}
\hline Langkah 3 & $\begin{array}{l}\text { Pengembangan format produk awal, dimana } \\
\text { mulai mendesain secara digital kartu } \\
\text { dengan menggunakan AI (Adobe Illustrator) } \\
\text { berdasarkan hasil data analisa kebutuhan } \\
\text { siswa SD Maria Asumppta Klaten. }\end{array}$ \\
\hline Langkah 4 & Tahap validasi produk awal, media kartu yang \\
& telah diproduksi, diuji oleh ahli materi dan \\
& ahli media. Kemudian diuji terbatas dengan \\
& melibatkan partisipan siswa sekolah dasar \\
& 4,5, dan 6 di SD Asumpta Kabupaten Klaten \\
& yang berjumlah 144 orang. Proses yang pada \\
& tahapan ini bertujuan untuk melakukan review \\
produk awal serta memberikan saran atau \\
komentar guna memperbaiki produk menjadi \\
lebih baik.
\end{tabular}

penelitian, khususnya siswa kelas atas, yaitu 4, 5, dan 6, yang berjumlah 74 orang siswa. 


\section{HASIL DAN PEMBAHASAN}

\section{Deskripsi Hasil Penelitian}

Penelitian dan pengembangan menghasilkan luaran pada setiap langkahnya. Pada penelitian ini ada 5 (lima) langkah yang digunakan. Pertama, tahap pengumpulan informasi awal dimana peneliti melakukan pengumpulan informasi berdasarkan SKKPD dan desain media yang merujuk pada standar BSNP (2006). Peneliti menyebarkan kuesioner untuk mengidentifikasi kebutuhan pengguna (siswa) dengan mengacu pada metode pembelajaran yang tidak disukai, jenis profesi yang ingin diketahui siswa, dan permainan yang disukai untuk pembelajaran.

Selain itu juga dilakukan wawancara pada sebagian siswa terkait permainan yang sering mereka mainkan, permainan berkelompok yang disukai, persoalan yang ada saat kegiatan klasikal, kegiatan klasikal yang diinginkan mereka dan media yang ingin dimainkan. Tahap ini melibatkan partisipan dari siswa kelas IV, V, VI SD Maria Assumpta Kabupaten Klaten sebanyak 74 orang siswa. Hasil pengumpulan informasi awal ini dapat dilihat pada tabel berikut:

Tabel 2.

\section{Hasil Identifikasi Informasi Awal}

\begin{tabular}{|c|c|}
\hline $\begin{array}{l}\text { Kegiatan belajar mengajar } \\
\text { (KBM) menggunakan } \\
\text { permainan sangat } \\
\text { menyenangkan }\end{array}$ & 47 dari 74 orang siswa $(63.51 \%)$ \\
\hline $\begin{array}{l}\text { tidak suka dengan metode } \\
\text { belajar dengan ceramah, dikte, } \\
\text { memberikan banyak tugas/ } \\
\text { PR, tidak ada permainan }\end{array}$ & 64 dari 74 orang siswa $(86.49 \%)$ \\
\hline $\begin{array}{l}\text { Ada } 5 \text { (lima) jenis profesi yang } \\
\text { sering disebut oleh siswa }\end{array}$ & $\begin{array}{l}\text { 1. Dokter (44 orang atau } 59,46 \\
\% \text { ) } \\
\text { 2. Masinis (43 orang atau } \\
58,11 \% \text { ) } \\
\text { 3. Guru ( } 34 \text { orang atau } 45,95 \\
\% \text { ) } \\
\text { 4. Tentara ( } 28 \text { orang atau } \\
37,84 \% \text { ) } \\
\text { 5. Polisi (42 orang atau } 56,76 \\
\% \text { ) } \\
\text { 6. Lain-lain }\end{array}$ \\
\hline $\begin{array}{l}\text { Permainan yang disukai } \\
\text { untuk pembelajaran }\end{array}$ & $\begin{array}{ll}\text { 1. } & \text { kartu (56 orang atau } 75,66 \\
& \% \text { ) } \\
\text { 2. } & \text { video/film (32 orang atau } \\
& 43,24 \% \text { ) } \\
\text { 3. } & \text { mengambar (12 orang atau } \\
& 16,22 \% \text { ) } \\
\text { 4. } & \text { cerita (9 orang atau } 12,16 \\
& \% \text { ) }\end{array}$ \\
\hline
\end{tabular}

Tabel di atas menunjukkan keterbatasan pengetahuan siswa akan berbagai profesi yang ada di Indonesia berdasarkan SKKPD yang ada.
Ketidaktahuan siswa akan berbagai macam profesi ini menjadi tantangan bagi guru bimbingan konseling. Seharusnya, pada tahap pengenalan dalam SKKPD mengatakan siswa mengenal ragam pekerjaan dan aktivitas orang dalam kehidupan. Guru harus menggunakan strategi dalam memberikan layanan informasi karier sesuai dengan SKKPD SD agar siswa memiliki pengenalan pada berbagai jenis profesi yang saat ini ada.

Kedua, tahap perencanaan. Tahap ini mulai direncanakan pengembangan produk. Pengembangan media pembelajaran memperhatikan beberapa aspek dalam produknya yaitu kesederhanaan, keterpaduan, penekanan, keseimbangan, bentuk, garis, warna dan testur (Arsyad, 2011). Pengembangan konten menggunakan Standar kemandirian siswa SD yang dikeluarkan oleh pemerintah. Aspek yang ada dari SKKP ialah perkembangan wawasan dan kesiapan karier. Aspek ini memuat 3 (tiga) tahap yaitu: (1) tahap pengenalan tentang mengenal ragam profesi dan kegiatan orang dalam kehidupan; (2) tahap akomodasi mengenai menghargai ragam pekerjaan serta aktivitas sebagai hal yang saling berkaitan; dan (3) tahap tindakan yaitu mengekspresikan ragam pekerjaan serta aktivitas orang di lingkungan kehidupan.

Pada tahap perencanaan juga dilakukan desain kartu, isi jenis profesi yang ditampilkan merupakan hasil survey yang diberikan pada 74 siswa SD kelas IV, V, IV. Tahap ini, dibuat daftar profesi sebanyak 559 buah yang didapatkan dari kombinasi KBJI 2016 (Klasifikasi Baku Jabatan Indonesia) yang dikeluarkan Kementerian Ketenagakerjaan serta Badan Pusat Statistik, dan Klasifikasi Jabatan BEKRAF dalam KBJI 2014 yang dikeluarkan Badan Ekonomi Kreatif pada tahun 2017. Dari 559 buah profesi, ada 134 profesi yang dipilih ingin diketahui oleh siswa.

Perencanaan proses pengembangan akan menggunakan perangkat lunak adobe illustrator sebagai perangkat lunak grafis vektor, yang akan berbeda dengan software grafis berjenis piksel seperti adobe photoshop dimana kualitas gambar yang dihasilkan lebih tajam. Selain perangkat lunak ini tepat untuk menggambar ilustrasi dan kartun.

Tahap ketiga adalah tahap pengembangan format produk awal yang meliputi isi materi kartu bergambar serta isi kartu petunjuk atau clue profesi sejumlah 134 profesi, serta instrumen-instrumen terkait evaluasi penilaian ahli. Tahapan selanjutnya, peneliti menyusun isi dan clue kartu bergambar yang sudah dibuat dalam tahap perencanaan. Tahap pengembangan produk awal ialah tahap dimana peneliti melaksankan pengembangan produk 
kartu bergambar berdasarkan hasil data analisis kebutuhan siswa SD Maria Asumppta Klaten. Tahap pengembangan format produk awal meliputi isi materi kartu bergambar serta isi kartu clue profesi sejumlah 134 profesi, serta instrumen-instrumen terkait evalusi penilaian ahli. Tahapan selanjutnya, peneliti menyusun tentang isi dan clue kartu bergambar yang sudah dibuat dalam tahap perencanaan. Tahap desain media kartu bergambar dilakukan dengan menyusun tulisan atau teks, gambar. Evaluasi desain dilakukan peneliti dengan menggunakan daftar centang yang diadaptasi dari Azwar (2014). Desain yang telah disusun selanjutnya dikembangkan dalam bentuk produk kartu bergambar profesi yang kemudian dibuat draft kartu dan didiskusikan dengan siswa sebagai calon pengguna. Draft sengaja dibuat 2 versi, agar siswa dapat menentukan pilihan salah satu dari kedua draft awal ini. Berikut gambar draft awal kartu:
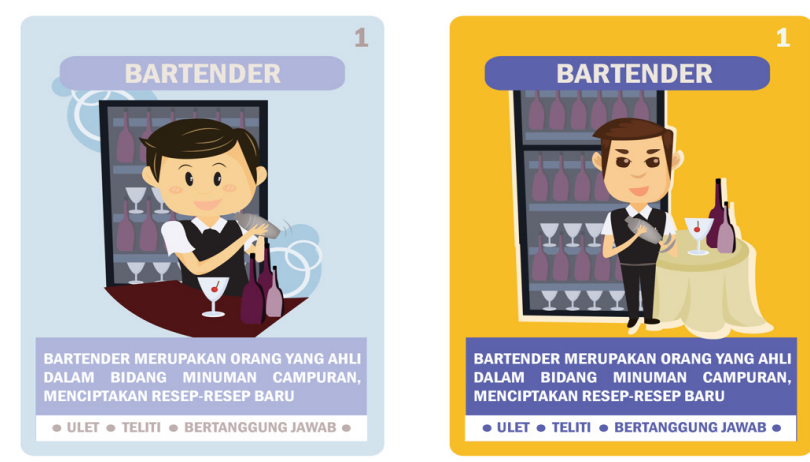

Gambar 3. Draft Awal Kartu Bergambar

Gambar di atas, merupakan desain awal yang dibuat berdasarkan pada 134 profesi yang berisikan deskripsi profesi serta nilai kekuatan diri. Deskripsi profesi berasal dari KBJI 2016. Desain kartu bergambar ini kemudian didiskusi dengan siswa dan menghasilkan tanggapan yang diharapkan siswa sebagai berikut ini :

Tabel 3.

Hasil Uji Pengguna Draft Awal Produk

\begin{tabular}{cclll}
\hline No & \multicolumn{1}{c}{ Aspek } & Indikator & Dipilih oleh & Persentase \\
\hline 1 & Karakter huruf & Bold & 70 & $94.59 \%$ \\
& & Biasa & 4 & $5.41 \%$ \\
2 & \multirow{2}{*}{ Warna } & Kuning & 59 & $79.73 \%$ \\
& & Biru & 15 & $20.27 \%$ \\
3 & \multirow{2}{*}{ Gambar karakter } & 1 & 51 & $68.91 \%$ \\
& & 2 & 23 & $31.09 \%$ \\
\multirow{2}{*}{4} & \multirow{2}{*}{ Garis gambar } & Menyolok & 74 & $100 \%$ \\
& & Lembut & 0 & $0 \%$ \\
\hline
\end{tabular}

Dari hasil diskusi dengan calon pengguna seperti pada tabel 3 di atas, menunjukkan bahwa siswa lebih memilih produk dengan karakter huruf tebal (bold), warna kuning, gambar karakter 1 dan dengan garis gambar yang menyolok, sehingga dibuatlah produk yang sesungguhnya pada bahan dengan kertas yang lebih tebal dan teknik pencetakan digital printing. Produk kartu bergambar profesi yang dikembangkan, memakai kertas berbahan Ivory 300 gr. Pembuatan desain meliputi jenis tulisan yang digunakan, gambar profesi. Tahap desain selanjutnya adalah bentuk dan ukuran kartu yang disesuaikan dengan responden yaitu $7 \mathrm{~cm} \times 8 \mathrm{~cm}$. Huruf yang digunakan memakai font 12 serta jenis huruf century. Desain kartu bergambar profesi memakai software adobe illustrator (AI) serta menyajikan gambar yang menarik dan relevan sesuai materi. Isi media kartu bergambar profesi ini dapat menikmati serta pemakai semakin tertarik untuk mempelajari setiap informasi profesi. Pengaturan warna, tulisan diatur agara bisa dibaca. Berikut hasil kartu informasi profesi:

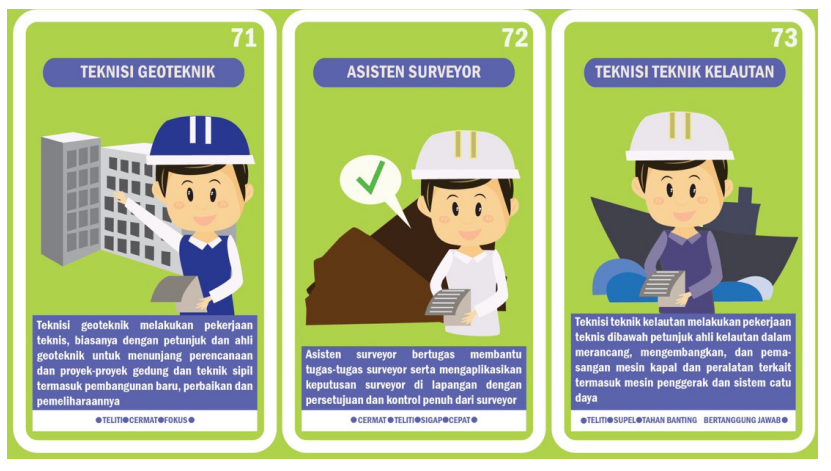

Gambar 4. Kartu Clue Informasi Profesi

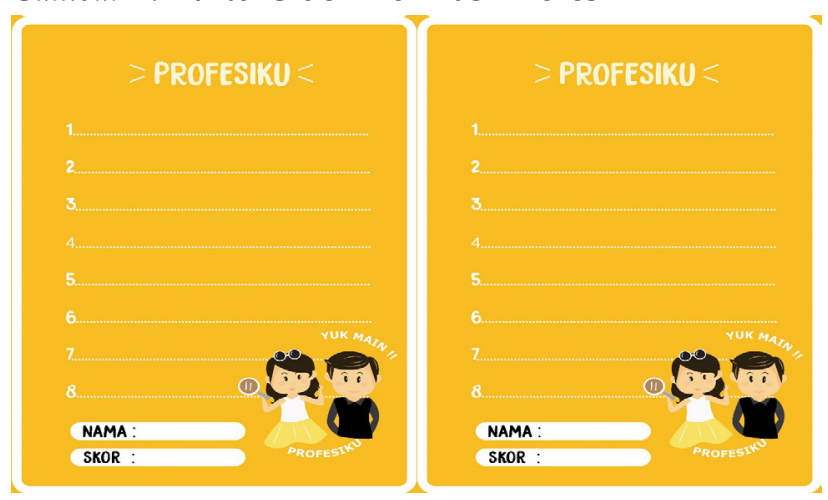

Gambar 5. Kartu Jawaban Permainan

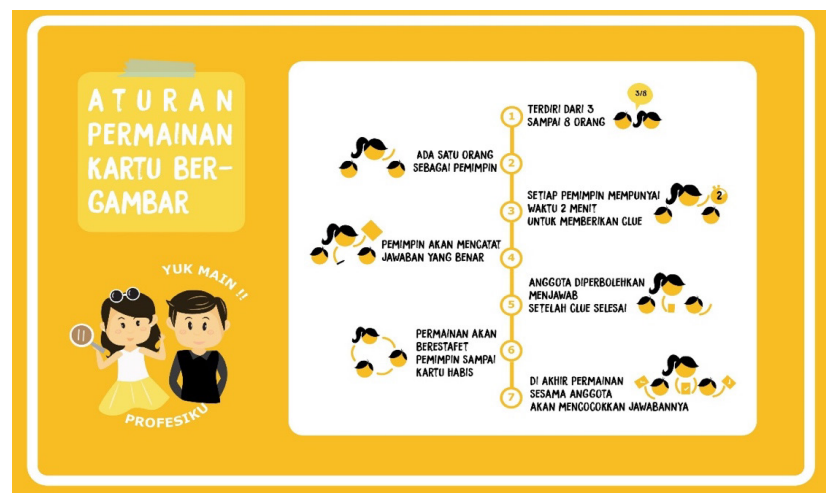

Gambar 6. Kartu Panduan Permainan 
Tahap Keempat, Tahap validasi produk awal, media kartu bergambar adalah mencetak gambar yang telah di desain menjadi bentuk kartu agar bisa digunakan untuk uji validasi produk. Ujicoba pengguna dilakukan dengan cara menggunakan media kartu bergambar sesuai dengan prosedur penggunaan yang telah dijelaskan sebelumnya. Setelah selesai, partisipan mengisi kuesioner tentang informasi profesi yang diharapkan ada dalam kartu bergambar, memberikan pendapat tentang produk dalam segi desain, warna, bentuk pada kartu dan terkait isi di dalam kartu bergambar seperti gambar, warna, grafis, dan visual atau desain kartu; dan tentang konten informasi profesi.

Berdasarkan dari hasil analisis data uji validitas yang dilakukan. Tahap validasi produk awal, media kartu bergambar adalah mencetak gambar yang telah di desain menjadi bentuk kartu agar bisa digunakan untuk uji validasi produk. Proses melaksanakan uji validasi produk awal, peneliti perlu mempersiapkan kisi-kisi serta lembar instrumen untuk penilaian dan memberikan saran agar ada perbaikan media kartu bergambar. Fase validasi dilakukan pada tanggal 29 Juli sampai 15 Agustus 2018. Tahap validasi dilakukan dengan melibatkan ahli materi, ahli media, dan pengguna.

Tabel 4.

Hasil Uji Ahli Media, Ahli Materi Dan Pengguna

\begin{tabular}{cccc}
\hline Aspek & Total Skor & Persentase & Kriteria \\
\hline Hasil Uji Validasi Ahli Materi & 105 & $78,09 \%$ & Layak \\
Hasil Uji Validasi Ahli Media & 175 & $90,28 \%$ & Sangat Layak \\
Hasil Uji Validasi Pengguna & 1037 & $78.52 \%$ & Layak \\
\hline
\end{tabular}

Hasil ahli materi dilibatkan untuk mengevaluasi kesesuaian kartu bergambar profesi dengan teori serta kegunaannya. Ahli materi yang dilibatkan ialah Dr. Dede Rahmat Hidayat, M.Psi yang merupakan dosen prodi Bimbingan Konseling di Universitas Negeri Jakarta. Beliau bertindak sebagai validator ahli materi yang melakukan validasi terkait apsek kelayakan, aspek kebahasaan, aspek penyajian, aspek tujuan informasi karier. Standar penilaian yang digunakan peneliti dalam uji coba validasi media kartu berujuk pada standar pengembangan media cetak dan desain versi BSNP (2006). Berdasarkan hasil penilaian yang telah dilakukan oleh validator ahli materi, terdapat beberapa catatan yang perlu diperbaiki adalah penyamaan informasi dalam kartu clue, penggunaan tata Bahasa yang jelas dalam setiap kartu clue, memberikan informasi yang efektif dan efisien pada setiap kartu clue. Terkait isi materi sudah baik, namun perlu ada poin informasi dalam kartu clue yang dihilangkan agar lebih mudah dipahami oleh pengguna. Kesimpulan yang dapat dijelaskan berdasarkan uji validasi ahli materi adalah produk media kartu bergambar dalam meningkatkan pengetahuan profesi dapat digunakan sebagai penelitian dan layak digunakan untuk uji coba lapangan dengan revisi

Hasil dari ahli media dilibatkan untuk mengetahui kualitas media kartu bergambar profesi. Dosen ahli yang dilibatkan adalah Cecep Kustandi, M.Pd. yang merupakan dosen jurusan teknologi pendidikan di Universitas Negeri Jakarta. Beliau bertindak sebagai validator ahli media yang melakukan validasi terkait aspek tampilan desain grafik kartu bergambar, tampilan fisik kemasan, tampilan desain garfik kemasan, tampilan fisik kartu karier, kemudahan penggunaan, konsistensi, formasi artistik, kemanfaatan, daya dukung, aturan penggunaan. Standar penilaian yang digunakan peneliti dalam uji coba validasi media merujuk pada standar pengembangan media cetak dan desain pesan versi BSNP (2006). Berdasarkan hasil penilaian yang telah dilakukan validator ahli media, terdapat beberapa catatan yang perlu diperbaiki seperti menempelkan tata cara bergambar dalam buku atau kemasan agar mudah dibaca serta tidak lepas, sobek atau hilang. Kesimpulan yang dijelaskan berdasarkan hasil validasi ahli media adalah produk media kartu bergambar untuk meningkatkan pengetahuan profesi siswa bisa digunakan untuk penelitian serta layak untuk dilakukan uji coba di lapangan tanpa revisi.

Pengguna dilibatkan untuk mengetahui kegunaan kartu bergambar profesi. 144 pengguna dilibatkan adalah siswa kelas atas SD Maria Asumppta Klaten. Siswa SD kelas atas bertindak sebagai validator yang akan melakukan penilaian terkait kartu bergambar, serta mengetahui keefektifan media kartu. Borg, Gall \& Gall (Ali, 2014) mengatakan bahwa peran validator pengguna adalah melakukan penilaian, memberikan saran/komentar serta membuat kesimpulan tentang media bergambar. Klasifikasi jumlah responden yang dijadikan sebagai validator pengguna merujuk pada pengembangan model Borg \& Gall (Sukmadinata, 2010). Tahap uji validasi produk oleh pengguna ini menggunakan instrumen penilain yang merujuk pada Badan Standar Nasional Pendidikan (2006).

Hasil uji coba memperlihatkan bahwa angka persentase sebesar 78,29 persen dari total skor 14656 dan skor ideal sebesar 18720. Hasil ini menujukkan bahwa perangkat permainan sudah dikatagorikan layak digunakan pada siswa kelas IV, V, VI SD 
Maria Asumppta Klaten. Berdasarkan hasil penilaian validator pengguna, terdapat beberapa catatan yang perlu dikoreksi antara lain, a) pemaparan informasi tentang clue yang kurang banyak, b) Instruksi Peraturan permainan serta cara bermain yang kurang mudah dipahami, dan c) waktu yang kurang lama untuk melakukan permainan yang dilakukan. Berdasarkan hasil validasi pengguna, dapat dijelaskan bahwa media kartu bergambar profesi mampu berkontribusi memberikan informasi kepada pengguna terkait pengetahuan profesi. Manfaat lain dari kartu bergambar ini adalah pengguna mendapatkan informasi tentang berbagai profesi yang ada di Indonesia.

Media kartu bergambar ini dibuat dengan desain yang menarik, praktis, mudah dibawa sehingga dapat dimainkan oleh semua anak. Inovasi media kartu bergambar profesi ini, dianggap berkontribusi untuk siswa serta guru karena minimnya media bimbingan konseling di sekolah dasar saat ini. Rerata persentase hasil validasi pengguna menunjukkan 72 siswa berada pada persentase lebih dari 80 persen atau sangat layak dan terdapat 72 siswa sebagai validator pengguna yang menunjukkan prosentase lebih dari 60-80 persen atau layak. Hasil keseluruhan penilaian uji pengguna sebesar 78.52 persen yang artinya adalah media kartu bergambar profesi terdapat pada skala kriteria layak.

Tahap kelima, merupakan tahap revisi terhadap produk media kartu bergambar. Revisi produk, berdasarkan penilaian serta saran atau komentar yang diberikan oleh validator ahli media, validator ahli materi, dan validator pengguna. Adapun beberapa hasil revisi produk yang telah dilakukan, dapat dilihat sebagai berikut ini:

a) Peneliti melakukan revisi pada produk media kartu bergambar atas masukan dari validator ahli media, yaitu memasangkan aturan dan cara bermain dalam kotak agar tidak mudah hilang atau rusak.

b) Atas saran yang diberikan oleh validator ahli materi, ada beberapa catatan yang perlu diperbaiki antara lain penyamaan informasi dalam clue kartu, penggunaan tata Bahasa yang jelas dalam setiap kartu clue, memberikan informasi yang efektif dan efesien pada setiap kartu clue. Tujuannnya agar pengguna memahami tentang materi yang disampaikan.

c) Berdasarkan saran dari coba pengguna, ada beberapa catatan yang perlu di perbaiki antara lain durasi permainan, Penambahan informasi tentang clue, Intruksi peraturan permainan serta cara bermain yang mudah dipahami dengan video.

\section{PENUTUP}

\section{KESIMPULAN}

Berdasatrkan hasil penelitian dan pengembangan yang telah dilakukan mengenai media kartu bergambar untuk meningkatkan pengetahuan profesi untuk siswa SD kelas SD Maria Asumppta Klaten, Kartu Bergambar profesi merupakan media informasi karier dalam bimbingan konseling, khususnya bimbingan karier. Media kartu bergambar untuk siswa SD kelas atas masuk ke dalam katagori layak. Berdasarkan hasil penelitian dan pengembangan, kartu bergambar dapat digunakan sebagai media pemberi informasi tentang profesi di Sekolah Dasar Kelas atas Maria Asumppta Klaten. Hasil penilaian yang diperoleh dari ahli media didapatkan hasil sebesar 90,28 persen dan masuk ke dalam katagori sangat layak sehingga dapat dilanjutkan dan digunakan sebagai penelitian. Hasil dari uji coba ahli sudah sangat baik, desain gambar sudah sesuai sehingga mudah dipahami oleh peserta didik atau pengguna.

Deskripsi mengenai tujuan dari permainan, serta cara bermain sudah baik karena dapat dipahami oleh peserta didik atau pengguna. Hasil penelitian yang didapatkan dari ahli materi, setelah dilakukan tabulasi sebesar 78,09 persen dan masuk dalam katagori layak sehingga dapat dilanjutkan dan digunakan untuk penelitian. Bedasarkan hasil evaluasi ahli materi, isi kartu clue harus disesuaikan atau disamakan isi kontennya. Isi kartu ini disamakan agar lebih mudah digunakan dan dipahami oleh pengguna. Hasil uji coba pengguna dilakukan pada 144 siswa SD kelas atas Maria Asumppta Klaten. Hasil penilaian dari validator pengguna menunjukkan persentase sebesar 78,52 persen. Persentase ini termasuk dalam katagori layak sehingga dapat digunakan.

Peneliti juga memiliki bebetapa keterbatasan, sehingga peneliti lain dapat mengembangkanya. Peneliti lain, mampu lebih bisa mengembangkan kartu bergambar profesi serta dengan jumlah profesi yang lebih banyak dan beragam., mengembangkan produk media kartu bergambar untuk meningkatkan pengetahuan pada subyek peneltian yang berbeda, sehingga tidak hanya terbatas pada siswa kelas atas SD Maria Asuppta Klaten., mengembangakan produk media kartu bergambar pada skala uji coba yang lebih luas, sehingga kartu bergambar dapat dipakai serta diproduksi secara masal, melakukan evaluasi pada produk media kartu bergambar untuk meningkatkan 
pengetahuan profesi anak SD kelas atas sehingga lebih diketahui keefektifannya.

\section{DAFTAR PUSTAKA}

AECT. (1977). The Definition of Educational Technology. Washington: Association for Educational Communication and Technology.

Alhadi, Said. (2016). Media in guidance and counseling services: a tool and innovation for school counselor. SCHOULID: Indonesian Journal of School Counseling (2016), 1(1), 6-11.

Ali, Lynda \& Graham, Barbara. (1996). The Counseling Approach to Career Guidance. New York: Routledge.

Arsyad, Azhari. (2017). Media Pembelajaran. Jakarta: Raja Grafindo Persada.

Badan Pusat Statistik. (2002). Klasifikasi Baku Jenis Pekerjaan Indonesia 2002 (KBJI 2002). Jakarta: Nario Sari

Budiningsih, Asri. (2003). Desain Pesan. Yogyakarta: Universitas Negeri Yogyakarta

Gall, D. M., Gall, P. J., \& Borg, R. W. (2003). Educational research: An introduction. Boston: Ablongman.

Geldard, K. \& Geldard, D. (2012). Konseling Anak-Anak Panduan Praktis. Ed 3. Yogyakarta: Pustaka Pelajar.

Gerlach, V. S.,\& Ely, D. P. (1980). Teaching $\mathcal{E}$ Media: A Systematic Approach (2nd ed.). Englewood Cliffs, New Jersey: Prentice Hall

Egbo, E John. (2015). Need For Guidance And Counselling At The Primary School Level: Early Intervention Strategies For School Children. British Journal of Education, 3 (6), Pp.1-8, July 2015. Ebonyi State University.

Hanani, Zati. (2016). Pengembangan Kartu Karir sebagai Media dalam Bimbingan Karir Siswa SD Negeri Samirono. Skripsi Tidak Diterbitkan. Yogyakarta: Universitas Negeri Yogyakarta. Diakses dari eprint. uny.ac.id pada 22 Oktober 2019

Lidyasari, Aprilia Tina. (2019). Inovasi Bimbingan Karir dalam Mengembangkan Career
Awareness Siswa Sekolah Dasar di Era Revolusi Industri 4.0. Proceeding dalam Konvensi Nasional XXI Asosiasi Bimbingan dan Konseling Indonesia Bandung, 27-29 April 2019.

NOSCA. (2012). Elementary School Counselor's Guide. South Florida: www.collegeboard.org.

Pranoto, Wahyu Hadi. (2015). Pelaksanaan Layanan Bimbingan Konseling oleh Guru Kelas di Sekolah Dasar Kabupaten Batang. Skripsi Tidak Diterbitkan. Semarang: Universitas Negeri Semarang. Diakses dari lib.unnes.ac.id pada 6 April 2019.

Purwanta, Edi. (1993). Penggunaan Gambar sebagai Teknik Bimbingan Karier di Sekolah Dasar. Tesis. Malang: IKIP Malang.

Sharf, R. S. (1992). Applying Career Development Theory to Counseling. USA: Brooks/Cole Publisihing Company.

Shertzer \& Stones. (1980). Fundamentals of Counseling. Boston: Houghton Mifflin Company

Saputro, Ari Wibowo. (2017). Implementasi Layanan Bimbingan Karier di SD Negeri Bulakan 02 Sukoharjo. Skripsi Tidak Diterbitkan. Surakarta: Universitas Muhammadiyah Surakarta. Diakses dari eprint.ums.ac.id pada 26 Oktober 2019

Sugiyono. (2016). Metode Penelitian Kuantitatif, Kualitatif dan RED. Bandung: Alfabeta.

Sugiyono (2017). Metode Penelitian $\mathcal{E}$ Pengembangan. Research and Develoment. Bandung:Alfabet

Super, D.E., Savickas, M.L. and Super, C.M. (1996). The life-span, life-space approach to careers. San Francisco : Career Choice and Development JosseyBass CA

Super, D.E. (1994). A life span, life space perspective on convergence", in Saviskas, M.L. and Lend, R.W. (Eds). Convergence in Career Development Theories, pp. 63-7. Palo Alto : Consulting Psychologists Press CA.

Winkel dan Hastuti. (2010). Bimbingan dan Konseling di Institusi Pendidikan. Yogyakarta: Media Abadi

Zunker, Vernon G. (2006). Career Counseling: A Holistic Approach Seventh Edition. USA: Thompson Brooks/Cole 
Pengelolaan Sekolah Dasar...

146 PERSPEKTIF Ilmu Pendidikan - Vol. 33 No.2 Oktober 2019 